\title{
Changing Trends in Outward Foreign Direct Investment of Turkish Companies
}

\author{
Ahmet Salih iKiZ \\ Faculty of Economics and Administrative Sciences (FEAS), Muğla Sitkı Koçman University, Turkey
}

Received June 30, 2019; Revised August 16, 2019; Accepted September 16, 2019

Copyright $\mathrm{C} 2019$ by authors, all rights reserved. Authors agree that this article remains permanently open access under the terms of the Creative Commons Attribution License 4.0 International License

\begin{abstract}
The phase of globalization has helped many developing economies in framing the path towards achieving a higher level of development and economic growth. One of the major instruments used in framing this path of economic growth is foreign direct investment. The economy of Turkey had also witnessed several economic crises and hence the liberalization reforms were introduced in early 2000, which have provided the Turkish economy a strong framework to expand in terms of foreign direct investment. In this context, the present study examines the impact of internationalization and foreign direct investment of Turkish companies. The researcher has collected the data for inward and outward FDI flows during the period 1990-2015. The researcher analyzed the trend of the FDI flows and explored the different reasons behind the rise in the amount of outward FDI. Further, the study explores the convergence of EU integration and how the internalization of Turkish companies changed the investment patterns among the multi-national enterprises in Turkey.
\end{abstract}

Keywords Foreign Direct Investment, Internationalization, Liberalization, Stability

\section{Introduction}

\subsection{About the Turkish Economy}

The IMF (International Monetary Fund) exemplified the economy of Turkey, also known as Eurasia, as the center of the economic and political area during the $20^{\text {th }}$ century. In the year 1990 large number of global firms like Microsoft, Coca-Cola, and Phillip Morris corroborated turkey as a prominent investment location and export platform and have selected it as the regional base (Özpençe, 2017). With its strong cultural and historic ties, it is the cardinal investor in central Asian Turkic republic and Caucasian and provides the perfect base for the business to develop with these countries (Akarca \& Tansel, 2006). Both the domestic and export-oriented opportunities provided by Turkey generally shaped its image as the destination for investment. The potential of Turkey has been recognized even by the international community. However, the economy has not surmounted that easily, its history has been marked with three important crises; the first one witnessed in 1994 and the last one in 2001 that left with the worst economic downturn turkey has ever experienced in his history (Bilgel \& Karahasan, 2016). Moreover, the economy has experienced many political conflicts, structural problems like high inflation, high unemployment, income inequality that limited the growth potential of the economy. However such perils finally paid off, with almost 40 years of struggle to integrate with EU and around 25 years of struggle to integrate with the rest of the economy, Turkey has now finally have taken step towards the new level of developments (Arguden, 2007).

Further, the future of the economy looks even more promising with its population growth rate falling from $2 \%$ to around $1.5 \%$. This population is on the verge of entering the golden demographic period in which the productive working population is relatively more than children and retirees and hence will provide the economy with the potential to grow even more rapidly (Coskun \& Gungormus, 2015). This situation can possibly act as the elixir for improving the competitiveness of Turkey in the global market (Kaartemo, 2012). There are only a few emerging economies in the world that have the potential to attract investors for export as well as for the domestic market. Turkey is in the privileged position to create such a vicious cycle with its more competitive business environment and thus could better serve the domestic market as well (Shaydullin, 2010).

\subsection{Foreign Investments of Turkey}

The impressive progress of Turkey in terms of economic stability and convergences has majorly increased the 
attractiveness of the country for foreign investors. Turkey has an exceptionally different case in terms of foreign direct investment as compared to other CEE countries. While the other CEE countries opened their economies to foreign direct investment in the 1990s, it started in Turkey since the post-war period. The FDI inflows that averaged around USD 0.8 billion in 1990-2000 reached USD 9.8 billion in 2005 and further grew to USD 20 billion in the year 2010 which was around $5.1 \%$ of GDP (Temiz \& Gökmen, 2009). Further, the factors such as political stability, sturdy economic growth, and banking and public sector reforms have put Turkey in the spotlight as the attractive destination for foreign direct investment (Revoltella, 2011). On further examining the FDI in Turkey for the time period 2012 it showed that it remained limited in the industrial sector while the major investments came to the service sector which accounted for around $90 \%$. The sectors such as financial intermediation and transport, storage and communication received the major FDI which was around 40\% and 36\% respectively (Esiyok, 2015). Investigation on the origin of FDI shows that around $82 \%$ of FDI came from Europe, of which the Netherlands held around $22 \%$ share, then Belgium with $16 \%$ of share followed by Greece and France with $10 \%$ share (Balasubramanyam, 2015).

Apart from inward FDI inflows, the outward FDI flows contributed to the growth of the Turkish economy. The very first Turkish outward FDI happened in 1932 by one of its privately-owned banks. Subsequently, the FDI outflow increased at an average annual rate of 26 percent during the time period from 1992 to 2004, it was second highest among the developing economies after that of India. It further registered an increase in the year 2004 in which the OFDI flows rose at an annual average of 1.6 percent from that of 0.6 percent in 1990-2000 (Erdilek, 2008).

\section{Research Aim and Objectives}

The aim of this study is to examine the impact of outward foreign direct investment in the Turkish companies for the time period 1990-2015. In accordance with the primary aim of the study, the researcher has framed the following research objectives:-

- To explore the inward and outward FDI trends in Turkey from 1990-2015 and find how it has affected the growth prospects there.

- To analyze the impact of economic crises and internationalization of Turkish companies on the investment patterns.

\section{A Paradigm Shift in the Turkish Economy}

The end of the cold war in the year 1991 was a very important event globally that left no state unaffected. Turkey underwent a paradigm shift in the systemic level leaving it with new foreign policy opportunity along with certain uncertainties. Throughout the 1990s, Turkey muddled through an unclear foreign policy framework. However, when the Justice and Development party came in power in November 2002 it brought a clear vision, a new direction and new strategies regarding foreign policies (Sözen, 2010).

\subsection{Oil Price Shock of 1970}

Energy is seen as a crucial input in an emerging economy. Oil being the most basic energy source is of great importance due to its role as the input to other sectors. Turkey is an oil-dependent economy, hence any volatility in oil prices affects it considerably. With almost $90 \%$ of its oil needs meet through imports, consequently, it is premeditated that the rise in oil prices have a considerable effect on the Turkish economy (Kooros \& Semetesy, 2010). The oil crisis of the 1970s caused significant changes especially on macroeconomic balances in Turkey. It not only increased the inflation and input costs but also decreased the demand for non-oil product indicating the lower purchasing power. The sectors which mainly got affected by this oil shock were manufacturing and transportation. This oil shock also distressed the employment levels in the Turkish economy in the short run as the weaker economic growth reduced the demand or labor. It also caused a rise in government expenditure and a decrease in taxes thus causing an increase in the budget deficit and interest rates (Wall \& Pringle, 2007).

\subsection{Liberalization and Deregulation Policies}

As the response to the failure of the economic system during the $1970 \mathrm{~s}$, the liberalization and deregulation policies were introduced in Turkey during 1980s. Turkey faced several economic challenges, balance of payment crises and an increased foreign dependency due an increase in oil prices. Many other developing countries faced the same issue due to a government-supported economic system, so these import-dependent economies were encouraged by developed economies to enter into an international market. This, in turn, reduced the level of government involvement (Alagoz, 2012). The main reason to shift towards liberal policies was the need to generate more surplus value by integrating with the world market. The liberalization in Turkey advocated the development model that was based on individualism and market liberalism. The main intention of the policies was to shift from import oriented policy structure to export-led growth and thus open the economy to external competition, reducing state role and support foreign investments (Aricanli \& Rodrik, 2014). For the implementation of liberalization policies, new structural adjustments were 
made by the IMF and the World Bank. The policies did lead to economic growth in Turkey for a limited time period. However, other macroeconomic variables were also taken into consideration like was this economic growth. This benefited nearly all the sections of the society, reducing the negative impacts of impact on poverty and unemployment (Greenaway \& Sapsford, 2015).

\subsection{Liberal FDI Law of Early 2000}

The year 1980 constituted as the major turning point in the history of the economic life of Turkey. It was the time period when the government of Turkey decided to shift their economy from inward-oriented to an outward-oriented system. This decision was followed by a series of economic reforms, financial liberalization being the most significant one (Cambazoglu \& Karaalp, 2014). By the end of 1999, the Turkish government launched a reform program through the support of the World Bank and the IMF in order to stabilize the economy. It liberalized its capital accounts, as the major step towards integrating with the rest of the world (Akgüç Alıcı \& Şengün Ucal, 2009). However, the financial liberalization led to currency substitution which aggravated the inflationary pressure and thus making the monetary policy ineffective although it did contribute to economic growth as well through its positive effect on private consumption. The structural reforms were quite successful in generating FDI inflows into the economy. The financial liberalization in spite of the unstable economic environment increased the capital inflows by more than four percent of GDP. Subsequently, Turkey became the major manufacturing base for many multinational firms thus bringing the corresponding increase in capital flows. As a result, both inward and outward flows witnessed a rapid increase in the early 2000 (Durnel, 2012).

\subsection{Economic Transformation}

The economy of Turkey has been successful in moving its resources, mainly labor, towards higher productivity modern industry and tradable sector from traditional agriculture. Its manufacturing sector absorbed a major rise in public and private investment in the year 2000, the share increased to 50 percent by 2008. Further, the diversification of exports in the tradable sector increased its productive capacity and its ability to compete along with this return on capital invested increased significantly (Hakura, 2013). According to the OECD (Organization of Economic Co-operation and Development), inequality reduced significantly in terms of income. The income gap which was around 18 times that of the poor in the year 2005 reduced to 14 times in 2009. Also the proportion of people below the poverty line reduced from 20.5 percent to 18.1 in the following years. However, poverty and equality indicators have become stagnant since 2010 (Tevfik F. Nas, 2013).

\subsection{Technological Improvements}

Turkey has given great importance to technology and has been paying considerable attention to this area since the early stage of technological revolution during the 1990s, by drafting a number of policy documents which focuses on raising computer literacy among people, supporting R\&D activities and transforming their economy to an information society. With the aim of boosting the competitiveness of Turkish ICT sector, it has been treated as the strategic sector in its Eighth Five Year Development plan (2001-2005). The main policy objectives included in the plan were stated as promoting electronic commerce, aiding competition in the telecommunication sector, improving internet and encouraging R\&D (Erdil \& Karagol, 2014). Further, technology development zones law were introduced in the year 2001 with the motive of accelerating technological progress. In the year 2003, an e-transformation turkey project was launched with the aim of rearranging policies concerning technological revolution and bringing it in the legal framework of EU. In 2004, the e-transformation board of turkey accepted Turkey's information society transformation policy program, according to which it focused on making turkey a focal point in the production of science and technology (Arapgirlioglu et al, 2007). In its ninth development plan which was for the period (2007-2013), disseminating technology was treated as a main economic and social priority with the motive of raising the competitiveness of the country around the globe (Reisman, Capar, \& Aktas, 2011).

\section{Theoretical Review}

\subsection{Emerging Markets}

Turkey has been the long-standing member of OECD and World Bank on the basis of GDP based ranking positioned it as $17^{\text {th }}$ largest economy in the world in the year 2015. The competition emerging in the external markets did not impact the country's International Political economy and thus continued to enhance its political reach. Due to its commendable economic growth, it has been placed in Group of Twenty, which is the group of world 20 major economies that focus on establishing financial stability (Goldthau, Keating, Kuzemko, \& Raszewski, 2018). However, after being the part of G-20 bloc and despite its impressive performance, the country is facing certain challenges like economic slowdown, negativity arising due to political risk, security issues due to war in its neighboring Syria and Iraq which is putting a negative impact on its emerging markets and thus adversely affecting the development strategies.

In order to sustain its economic path, the country is likely to increase its energy consumption and add pressure to its demand-side through its economically active 
population (Daron Acemoglu, 2015). The emerging market of Turkey provides both advantages and disadvantages in terms of internationalization and FDI. The centrality of its position provides benefit in terms of trade, transportation, and geographic proximity. Moreover, its large market size, more demand for products and services attract even more FDI. However it's political and security issues negatively affect the FDI (Apaydin, 2010).

\subsection{Advantages of Outward Foreign Direct Investment}

The institutional and structural transformations in Turkey after the devastating economic crisis of 2000-2001 has significantly improved the business climate along with the increased global capital flows which have resulted in enhanced economic growth. Further, the countries share in the international trade expanded with an increase in momentum of integration with the rest of the global market (Armutlulu et al, 2011). However, since 2010 it is experiencing reduced economic growth and increased volatility indicating the fragility in the countries growth. This has depressed the FDI inflow but on the other hand, FDI outflows have shown a continuous upward trend. Although the stock is small as compared to big players like China and India, its growth is still noteworthy (Yildirim, 2017). The emerging economies use outward investment as a technique to acquire strategic resources and assets so as to compete efficaciously at home country and with the world. This also helped the economy to overcome the problems of institutional and market constraints and offered with benefits of low input cost like energy, labor, and taxes (Armutlulu et al., 2011).

\subsection{Socio-economic Conditions}

With the improvement in the business climate and high growth rate constantly, the socio-economic factors also increase the country's significance on international platforms. The youthful population of Turkey offers a wide range of opportunities and the country in order to get benefited from this need to increase its employment rates and labor market participation. However, the unemployment rates in turkey have been more than $10 \%$ in the year 2006. In the time of the global crisis, it increased to $16.1 \%$. The employment rates are especially low for women. These all factors are operating against Turkey's youthful population advantage (Cidob, 2011). The inequality in terms of education levels between men and women still persist to deal with especially in terms of primary school enrolment, public campaigns have been introduced. The inequality between regions have also come up as the big issue especially the enrolment level have declined after the primary school in the less developed regions dramatically. The problem relating to the quality of education is again a major challenge faced by turkey. Focusing on the health and well-being, the TURKSTAT showed that life expectancy was 73.6 in Turkey in the year
2010. The crude birth rate is 6.3 per thousand people and the infant mortality rate is 13.2. Turkey has progressed a lot in terms of infant mortality rate which was 85 per thousand during 1985 (Özaslan, Dincer, \& Özgür, 2011).

\section{OFDI Pattern of Turkey}

Turkey has followed statist industrialization strategy from its foundation in 1923 to the 1980s, followed by the economic liberalization in 1990s that focused on the integration with the rest of the world. Further, its inward-looking industrialization strategy protected its private sector which resulted in very limited outward FDI mainly due to protectionist policies and restrictive regulations. Though with the onset of economic reforms, the outward FDI witnessed a major rise, it is important to analyze the pattern of such growth over the period of time (Yildirim, 2017).

\subsection{The Rise in Turkish MNEs}

With the radical adjustments in the Turkish economic structure in 1980 due to liberal policies adopted by the government, the country has seen a significant increase in the number of MNE's. The destination of investment by these MNE's is mostly the OECD countries. Germany and the Netherlands emerged as the major trade partners where the Turkish enterprises entered into an agreement with the foreign companies. The MNE's of Turkey is majorly engaged in the service sector, almost $72.2 \%$ established and around $63.9 \%$ of capital invested in Turkey is realized in the service sector. On the other hand, the share of the industrial sector in Turkey is around $41.5 \%$ further its share in agriculture and mining sector is even more limited to $1.5 \%$ (Sat, 2011). The emerging market of turkey has provided great opportunities for the MNEs to grow, with its huge consumer base and high demand for product and services by its economically active population. However, it has also faced certain challenges which vary from country-specific to company-specific. In a broader sense the main challenges that the MNEs faced in Turkey range from strategic decisions, management approach, to achieve sustainable growth and profitability while contributing to the overall wellbeing of the society (Khan, 2014).

In order to overcome the challenges and to enter the global market MNEs in Turkey adopted four different strategic behaviors which were as follows: drop and diffuse by adaption and challenging the incumbents. The first is the drop and diffuse by adaption is the strategic behavior used by the firms to enter the highly competitive foreign market and exploit its resources and capabilities. The typical example of this is Hayat Kimya which operates in FMCG who used this strategy to make the initial entry in the foreign market. The basic strategy is that company initially try to seize the small share of the targeted market where they find comparatively less competition and pressure from 
the incumbent side and then expands its offerings in that market (Ayden, Demirbag, \& Tatoglu, 2017). The second strategy is masking the emerging country multinationals in which firms target the competitive market in developed countries, the Turkish firms like Ziylan and Vestel adopted this strategy in which they got themselves engaged in sophisticated markets. However, this makes their existing resources and capabilities become less competitive. Thus the company pursues the acquisitions and camouflage so as to gain access to the assets that it lacks (Ayden, Demirbag, \& Tatoglu, 2018).

\subsection{The Outward and Inward Flow of FDI}

The FDI is generally categorized as the inward FDI and the outward FDI where inward FDI refers to the investment made by the foreign investors in the host country which through its competitive effect leads to a positive distribution of resources and thus improves the standard of living in the host country. The outward FDI, on the other hand, is the investment made by the domestic investors in the host country (Cambazoglu \& Karaalp, 2014). As already seen, Turkey had essentially been a closed economy before the 1980 s but after the several liberalization reforms in 1980, the Turkish economy has become much more open to international trade and capital flows. However, Turkey has failed to attract much FDI and has lagged behind relative to other developing economies. The reason for this failure has been both economic and non-economic, the main economic reason includes high cost of entry and operations due to extreme bureaucracy and red tape, economic instability, soaring rates of inflation, lack of intellectual property rights. The non- economic reasons, on the other hand, include political instability, fear of foreign political domination and internal conflicts were some of the factors that discouraged foreign investors (Erkilek, 2008).

Turkey's outward FDI, on the other hand, has registered a much faster growth rate than the inward FDI. The outward flow of the capital has been due to both economic and political factors. In a way inward FDI also helped the outward FDI to grow by providing Turkish firms with more competitiveness through knowledge spillover and by making the domestic investors explore foreign market by enhancing the competition in the domestic market (Vale, 2011). The data for the inward and outward FDI for the time period 1990-2015 has been presented in the table below.

Table 1. Inward and FDI flows

\begin{tabular}{|c|c|c|c|c|}
\hline Year & Outward FDI (billion US\$) & Inward FDI (billion US\$) & Outward FDI (\%GDP) & Inward FDI (\%GDP) \\
\hline 1990 & -16 & 6.84 & 0.01 & 0.45 \\
\hline 1991 & 27 & 8.10 & 0.018 & 0.54 \\
\hline 1992 & 65 & 8.44 & 0.041 & 0.53 \\
\hline 1993 & 14 & 6.36 & 0.031 & 0.35 \\
\hline 1994 & 49 & 6.08 & 0.037 & 0.47 \\
\hline 1995 & 113 & 8.85 & 0.067 & 0.52 \\
\hline 1996 & 110 & 7.22 & 0.061 & 0.40 \\
\hline 1997 & 251 & 8.05 & 0.132 & 0.42 \\
\hline 1998 & 367 & 9.40 & 0.133 & 0.34 \\
\hline 1999 & 645 & 7.83 & 0.252 & 0.31 \\
\hline 2000 & 870 & 9.82 & 0.319 & 0.36 \\
\hline 2001 & 497 & 33.52 & 0.248 & 1.67 \\
\hline 2002 & 143 & 10.2 & 0.06 & 0.45 \\
\hline 2003 & 480 & 17.02 & 0.154 & 0.55 \\
\hline 2004 & 780 & 27.85 & 0.193 & 0.69 \\
\hline 2005 & 1064 & 100.31 & 0.212 & 2 \\
\hline 2006 & 924 & 201.85 & 0.167 & 3.65 \\
\hline 2007 & 2106 & 220.47 & 0.312 & 3.26 \\
\hline 2008 & 2549 & 198.51 & 0.333 & 2.6 \\
\hline 2009 & 1553 & 85.85 & 0.241 & 1.33 \\
\hline 2010 & 1469 & 90.99 & 0.192 & 1.18 \\
\hline 2011 & 2330 & 161.82 & 0.258 & 1.94 \\
\hline 2012 & 4107 & 137.44 & 0.47 & 1.57 \\
\hline 2013 & 3536 & 135.63 & 0.383 & 1.43 \\
\hline 2014 & 6685 & 133.37 & 0.755 & 1.43 \\
\hline 2015 & 4811 & 192.74 & 0.593 & 2.24 \\
\hline
\end{tabular}

(Source- UNCTAD World Development Report) 


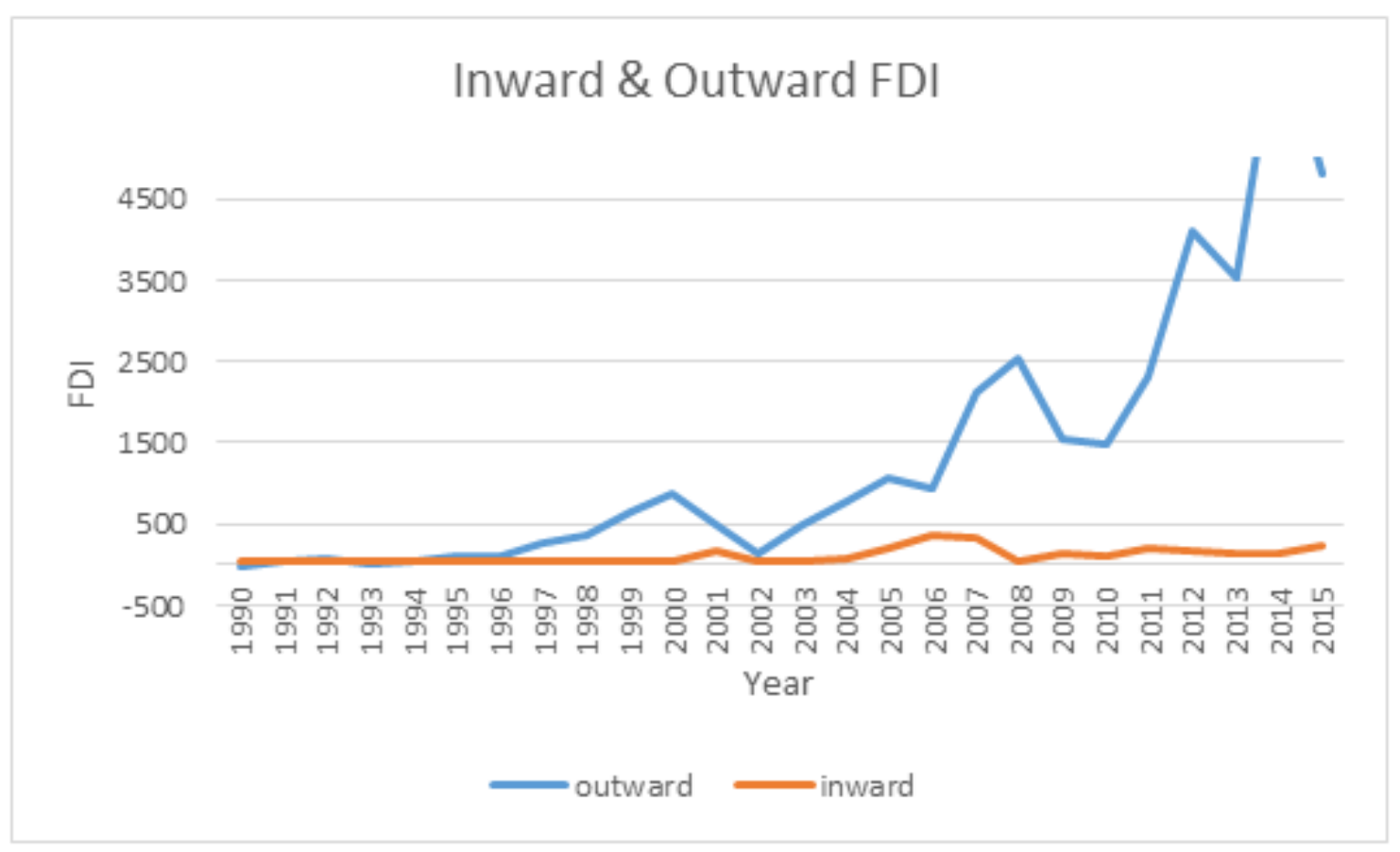

Figure 1. Inward and Outward FDI patterns

The above table presented the data on the inward and the outward FDI of turkey for the time period 1990-2015. Since the time of liberalization Turkey's outward FDI level has shown commendable growth rates. However, Turkey has not been successful in attracting FDI inflows mainly due to instability in its economic structure. But the liberalization which resulted in increased competitiveness within the country leads the investors in the home country to go outside and invest. As shown in the above table the outward FDI has increased since 1990 even the economic slowdown during the world crises did not affect the OFDI from Turkey.

The above figure highlights the trend of inward and outward FDI flows during the period of 1990-2015. The figure clearly indicates that the outward FDI flows increased after early 2000. This increase was due to both internal and external factors. The internal causes included the opening of Turkey to the inward investment after the liberalization which increased the competition in the domestic market and made the Turkish firms to go abroad in order to earn higher profits. However, the outward FDI among the Turks is still seen as capital flight and they perceive it as an activity that steals jobs. Since there is no insurance cover for the companies investing abroad nor any support from the government side in terms of providing information regarding the local conditions of the country in which firms are planning to invest (Deichmann, Karidis, \& Sayek, 2013). However, the government has taken certain measures in this respect for example in 2006 HoldCos 4 was put in place that provided exemption on the corporate tax on the income received from foreign ventures. However, companies were required to fulfill certain conditions first for becoming eligible for this exemption like $75 \%$ assets of the company must have shares in foreign affiliates and the share must have been held for the minimum two years' time period. Further, in order to provide support to the firms, the government initiated the program known as Turkquality which aims to develop the trademarks in areas ranging from textile, food processing, electronics, and automotive sector. This will help the firms to achieve global competitiveness (Tatoglu \& Erdal, 2012).

\subsection{Spatial Distribution of Turkish Companies}

The initiation of liberalization in the turkey provided a framework for the economic structuring. With the growth in links with the regions such as Balkans, Middle East, and North Africa the country expanded its share of international trade. The country in order to open new markets for its exporters promoted trade and the investments in this region through several trade agreements and visa agreements (Celebioglu \& Dall'erba, 2010). Turkey directed its investments mainly towards the European countries with 88 out of the 115 targeted firms were based in Europe, within Europe, it mainly targeted the countries such as Germany where it has 14 acquisitions, 11 acquisitions in Italy and 8 acquisitions in the Russian federation. This distribution shows that turkey mainly followed the regional orientation than the global orientation, the similarity in terms of economics, geography, politics, and spatial proximities allowed the multinational in turkey to conduct its international activities (Yildirim, 2017). 


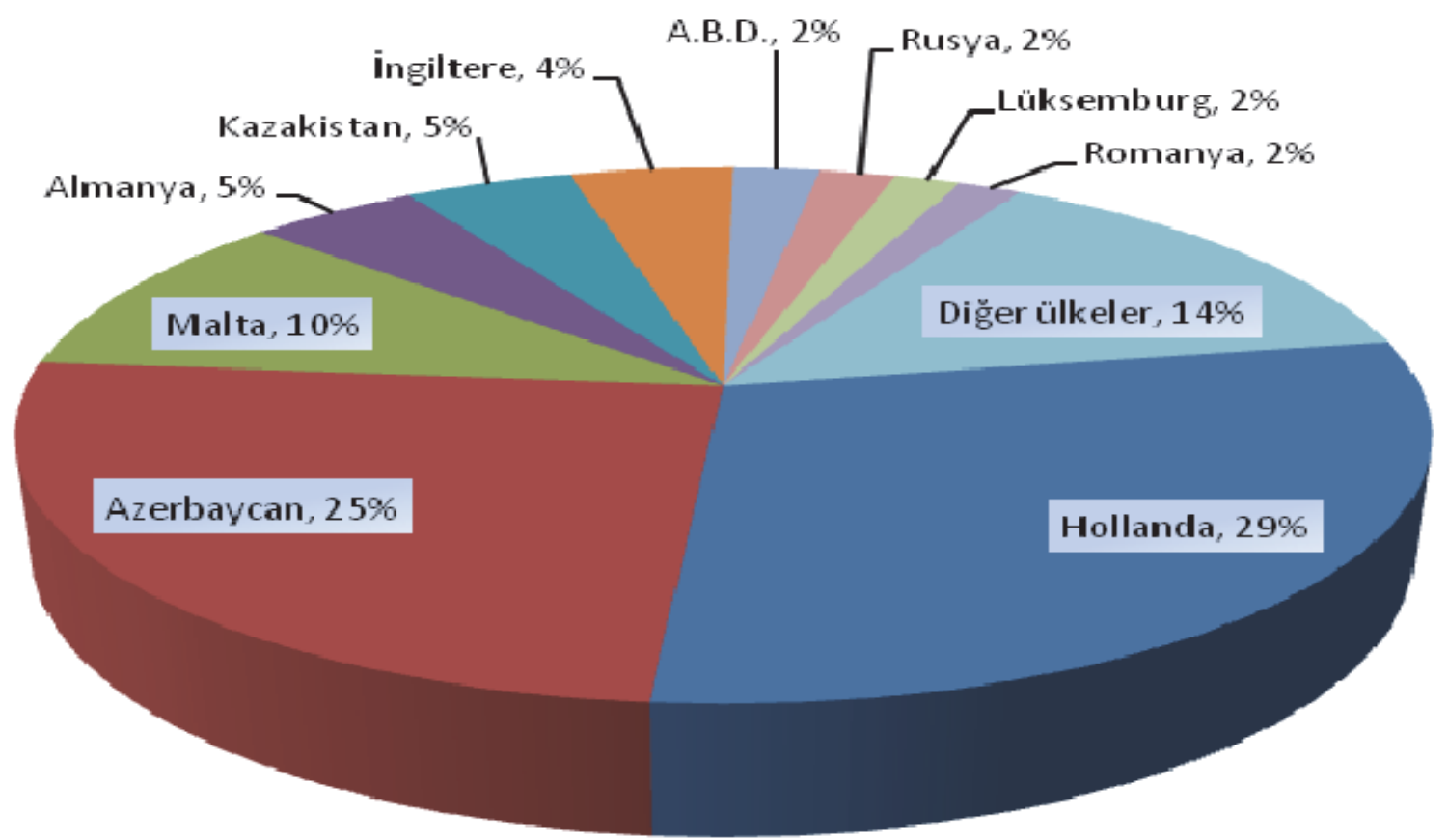

Source :(Yavan, 2012)

Figure 2. Share of OFDI Distribution Volume

The above figure highlights the spatial distribution of OFDI in the Turkish economy. As shown in the figure Turkish firms have followed the regional orientation instead of global orientation. As shown in the figure turkey had its major investments in Azerbaijan and Holland, where it shares land borders with Azerbaijan and Holland being the part of Europe and the major investments from turkey has been directed towards Europe only (Keyhani \& Madhok, 2012).

\section{Impact of EU Convergence}

The association between turkey and EU has been based on the Ankara Agreement which was signed on 12 September 1963 but entered into force on 1 December 1964. It was decided that turkey's full membership which was the final goal of the association will take place through three stages: preparatory stage, transitional stage, and the final stage. The transitional stage which was signed on 23 November 1970 and entered into force on 1 January 1973 stated that customs unions should be established between the parties, free movement of workers should be allowed and a preferential regime should be implemented in the agricultural products. However, the things did not happen as expected; it came to a freezing point in the 1980s. Following this, in 1989 it was decided that Turkey was eligible for the membership (Prime, 2012).

\subsection{Impact of EU Membership on OFDI}

The EU partnership has been a political and economic anchor for Turkey. The structuring of the Turkish economy and its integration with the EC has actually made a positive impact on the outward FDI from Turkey. Turkey started making negotiations which actually provided more investment opportunities on the one hand and attracted the FDI on the other hand. However, the late entry of Turkey in the EU as compared to Central and Eastern Europe restrained certain investment opportunities (Isiks, Isiksal, \& Jalali, 2018). The adoption of the common external tariff with the elimination of all quotas, customs duties helped Turkey significantly boost trade. Investing abroad was no longer seen as the issue that will steal the jobs from the Turks and moreover, regulations related to it was eased so this lead to increase in outward foreign direct investment from US\$ 0.86 million in the year 1980 to US\$ 92.81 million in the year 1988 (Apaydin, 2009).

Certain issues such as political-uncertainty, macro-economic volatility resulted in limited inward foreign direct investment in the country, thus in 1990s turkey lagged behind the other economies that were in the developing stage. However, all this acted as the push factor for Turkey's outward foreign direct investment that recorded the surge in the 1990s (Yildirim, 2017). With the liberalization of OFDI along with the capital account liberalization proved to be as the turning point for the OFDI which remained limited to the areas of western Europe. Another factor that added to the growth of OFDI was the dissolution of the Soviet Union that increased the business opportunities for the Turks. Due to this, the OFDI increased from US\$111.50 million at the end of 
1989 to US\$ 1.43 billion in 1996. Further, the OFDI from Turkey reached US\$2.45 billion at the end of 1999 but fell to US\$ 1.45 billion in year 2001(Taylor \& Kosekahyaoglu, 2010).

\subsection{Suspension of Membership}

The turkey-EC association was marred with disappointments and alienation. With the high expectation in the early sixties time period, the Turks began to feel that this association is offering more of liabilities than the advantages. The Turks attributed the economic crisis since 1975 to the inequitable terms of the EC association. Further, the Turks became even more apprehensive when the new protocol was signed in 1970 which presented considerable threats for the Turkish industrialization which was not very comforting for the Turkish government. Further, the 1973 oil crises and the 1974 war in Cyprus affected Turkey's relationship with EC even more adversely. It was unhappy with the EC since it felt that they supported Greek demands more without giving appropriate recognition of Turkish rights. Conditions that further added to this disappointment was the fact that it did not receive material aid from European allies during the time of difficulties caused by United States arms embargo (Bahcheli, 2013).

There have been many unacceptable steps taken to block Turkey's progress towards the EU. The first was the "absorptive capacity" approach given by France so as to prevent the turkey's full membership according to this approach Turkey was too big to be absorbed by EU in political, economic and cultural terms. The approach further presented that accession will harm the economic strength, resources and cultural identity of Turkey. The second step taken to block the membership was the concept of "privileged partnership" this was given by France and Germany. According to this concept, Turkey will be closely tied to EU like in terms of security but it could not participate in EU institution and will face visa restrictions, this step was not only unacceptable but it deepened the process of suspension. The Turkish government rejected this proposal. Both the concept of absorption capacity and a privileged partnership was provided as theoretical on the ground but in reality, they were, in fact, highly political moves (Keyman \& Aydın-düzgit, 2013).

\subsection{Convergence in the EU Integration Process}

After the stage of disappointments and alienation, there has been bolstering of views both from turkey and EU which expresses their concern regarding the gridlock in relations between Turkey-EU. Reinvigorating the Turkey-EU relationship will not only benefit Turkey and Europe but is also important for the stability and peace worldwide. The first step to resuming the accession is the lifting of vetoes and transforming relationship so as to respond globally. The EU turkey joint actions could provide each other with a wide scale of benefits ranging from economics to politics, culture and foreign policy (Schönfelder \& Wagner, 2019).

The EU anchors, the EU single market and the EU axis in foreign policy could make important contributions to Turkey on the one hand and on the other hand, Turkey's economic dynamism, entrepreneurial culture, its democracy could be beneficial for EU as well. The more flexible mode of membership was exercised so as to overcome the flaws that happened previously. The Eurozone crises further increased the need for integration from Europe point and to have closer political integration concerning the fiscal and monetary union. Turkey has its own reasons for joining the EU, Turkey being the economic dynamism had its trade relations at the global level so thus it needed the full membership in which it could join the political and security institution and the single market while it remains outside the Eurozone thus forming a flexible mode of membership (Barry, 2013).

\section{Internationalization of Turkish Multinationals}

A firm while trying to expand can choose among three modes of internationalization that are either by exporting, licensing or the FDI and the decision is made on the basis of the advantages provided that are of either ownership, location or of internalization. Of all three modes of internationalization, FDI requires the internalization advantage to be present so as to minimize the transaction cost. In the Turkish economy, firms tried to emphasize on market imperfections and tried to maximize the returns on the non-financial proprietary assets majorly the technology ones (Erdilek, 2008). The process of internationalization in the Turkish economy is mainly based on learning from international experiences and operations over time. The enhanced knowledge about the market and the better commitment towards the market has helped the Turkish firms to better penetrate. Since the operations in a foreign land are generally risky, the firms tend to choose the firms for the internationalization that is close to their home country (Yaprak, Yosun, \& Cetindamar, 2018).

During the early period of 1980s Turkish firms mainly focused on exporting due to export incentive regulations of that time and expanded in the markets such as EU, Middle East, and North Africa. The expansion of the Turkish firm was possible due to the free trade agreement and regional cooperation. Further in the same time period i.e. 1980s Turkish firms showed further improvement in terms of production capabilities, the share of industrial goods increased to 87 percent in the total exports (Keyhani \& Madhok, 2012). In the 1990s firms in Turkey started entering the international business activities which included building joint ventures and strategic alliances with the countries such as Germany, Netherlands, and 
England. Even the crises of 2008 and 2009 did not affect the international business of Turkey. The foreign investment was about 2 billion US dollar in 2004 which recorded as high as 20 billion in 2008 and 22.5 billion in 2009 (Cuervo-Cazurra, 2012). Turkish firms focused on three different forms of investments which are: industrial production investment, international venture, and financial investment. The rate at which Turkish firms established their branches in the foreign countries was around 73 percent, followed by establishing a new partnership rate which was 19 percent in the year 2010. The Turkish firms have further expanded in terms of their participation through outflows of foreign direct investment and cross borders mergers and acquisitions. The outward flow of FDI from turkey rose from $\$ 6$ billion in 1980 to $\$ 25$ billion in 2007 (Yaprak \& Karademir, 2010).

\subsection{Investment Patterns}

The liberalization in the Turkish economy has turned it into an open economy which has resulted in increased investments both inward and outward. Since then outward investments have surged up with crossing the US\$ 1 billion mark in 2005, the outward FDI fell in 2006 to US\$ 924 million but again jumped in the next year to US $\$ 2.1$ billion. There was again a fall in the year 2009 to US\$ 1.6 billion. The global economic downturn has put a certain pressure on Turkish MNEs in terms of investment made by them. But this is not with all the markets where Turkey invests like in EU, Germany, and France the investment has increased. The tight budget control and cuts in expenditure have enabled the Turkish investments to afloat in the EU. The Turkish firms have responded to the global slowdown by mainly slowing down the production process, drawing the value of their stocks down, product diversification and regional diversification (Dumludag, 2009).

The service sector of Turkey that included construction, communication, and energy financed their investments through long term project financing. The service firms faced the technical support problem in the first stage of their investments and shortage of the workforce in the later stages. The construction sector, on the other hand, has proved to be the most locomotive of OFDI by Turkish firms and the major destination of investment was sub-Saharan Africa and central Asia. The investments made in the textile sector were do adversely affected by the economic downturn, the main reason was the shrinking of the credit market in which it was heavily dependent (Grubaugh, 2016). When talking about Turkey's investment pattern it is necessary to show how turkeys top 19 MNE'S have placed themselves on the world forum and have integrated with the rest of the world. Table 2 presents the data relating to the top 19 MNE's of Turkey and how much foreign assets they held.

Table 2. Top 19 Turkish non-financial MNE's foreign assests, 2009

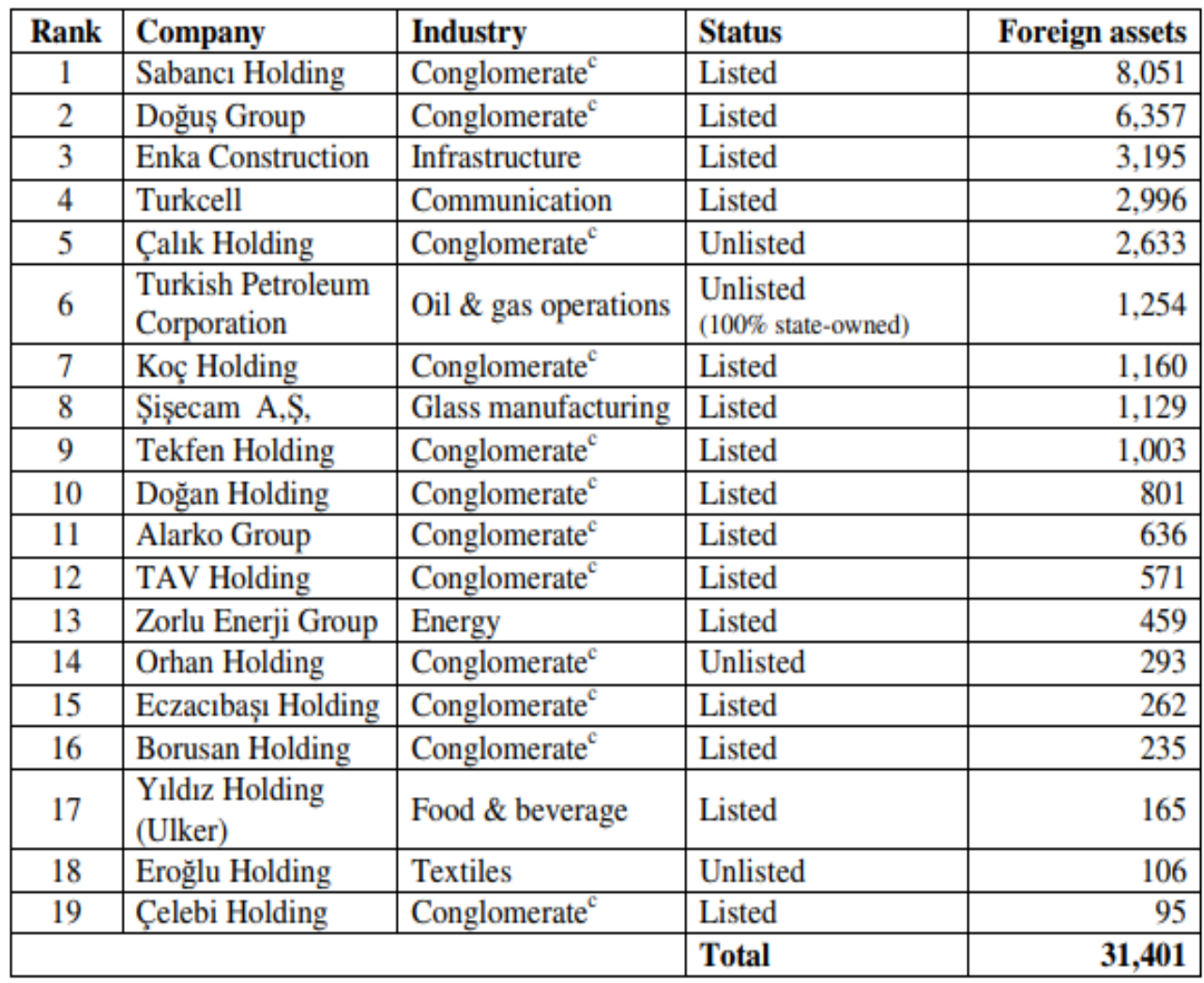

Source: KHU-KPMG-T-DEIK-VCC survey of Turkish multinationals, 2010 (Vale, 2011) 
Earlier the numbers of companies listed were 12 which increased to 19 in December 2009. Out of these 19 companies only 4 companies are not listed on stock exchange. The companies hold the asset around US\$ 31 billion together in the year 2009 with top ranked being the Sabanci holding which accounted for around US\$ 8 billion and second being the Dogus Group which accounted for more than US\$ 6 billion. The share of the top 19 companies was twice more than the total outward FDI which was below US\$ 15 billion and had given employment to around 90,000 workers in 396 foreign affiliates.

\section{Conclusions}

The present paper tried to study the internationalization and outward foreign direct investment made by Turkey along with this paper also shed the light on the regional policy choices and the role FDI played in reducing the imbalances across the different regions of turkey. The emerging market of Turkey has received noteworthy amount of attention in the last two decades. The main reason to shift towards the liberal policies was the need for large scale domestic groups so as to create more surplus value by integrating with the world market. Its objective has been the integration of their emerging market into the global economy through the full membership of European commission. The economy of Turkey has been successful in moving its resources, mainly labor, towards higher productivity modern industry and tradable sector from traditional agriculture. While it has tried to make full utilization of certain opportunities but it was found that it did face certain challenges within the region and at the home. The oil crisis of the 1970s, caused significant changes especially on macroeconomic balances in turkey, it not only increased the inflation and input cost but also decreased the demand of non-oil product indicating the lower purchasing power.

The sectors which mainly got affected by this oil shock were manufacturing and transportation. This oil shock also distressed the employment levels in the Turkish economy in the short run as the weaker economic growth reduced the demand or labor. Further, after the devastating economic crisis of 2000-2001, the institutional and structural transformations in turkey has significantly improved the business climate along with the increased global capital flows which have resulted in enhanced economic growth. Further, the countries share in the international trade expanded with an increase in momentum of integration with the rest of the global market. The present study focused only focused upon the trends of outward FDI and investment patterns of the Turkish MNE's. The study did not analyze the impact of the increase of FDI on the economic growth of Turkey. This has limited the scope of the study. Hence, the future studies must target upon analyzing the impact of rise in inward and outward FDI flows on the consumption, investment and the economic growth of the country.

\section{REFERENCES}

[1] Akarca, A. T., \& Tansel, A. (2006). Economic performance and political outcomes: An analysis of the Turkish parliamentary and local election results between 1950 and 2004. Public Choice, 129(1-2), 77-105. https://doi.org/10. 1007/s11127-005-9013-9.

[2] Akgüç Alıcı, A., \& Şengün Ucal, M. (2009). FOREIGN DIRECT INVESTMENT, EXPORTS and OUTPUT GROWTH of TURKEY: CAUSALITY ANALYSIS. International Journal of Humanities and Social Sciemce, (September).

[3] Alagoz, R. (2012). The Impacts of Neo-Liberal Policies on Turkey in 2000-2001.

[4] Apaydin, M. (2009). Analyzing FDI trends in emerging markets: Turkey vs CSEE and the Middle East. International Journal of Emerging Markets, 4(1), 72-97. https://doi.org/10.1108/17468800910931689.

[5] Apaydin, M. (2010). Analyzing FDI trend in emerging markets: Turkey vs CSEE and the middle east.

[6] Arapgirlioglu, H., Atik, A., Elliott, R., \& Turgeon, E. (2007). Researches on Science and Art in 21St Century Turkey. (November), 1454

[7] Arguden, Y. (2007). An overview of the Turkish economy: outlook and current perspective. (4).

[8] Aricanli, T., \& Rodrik, D. (2014). An overview of Turkey's experience with economic liberalization and structural adjustment. World Development, 18(10), 1343-1350. https://doi.org/10.1016/0305-750X (90)90114-D.

[9] Armutlulu, I., Anıl, İ., Canel, C., \& Porterfield, R. (2011). The Determinants of Turkish Outward Foreign Direct Investment. Modern Economy, 02(05), 717-728. https://doi.org/10.4236/me.2011.25080.

[10] Ayden, Y., Demirbag, M., \& Tatoglu, E. (2017) Characteristics and pattern of Turkish MNEs' Internationalization. In Turkish Multinationals. https://doi. org/10.1007/978-3-319-57294-9.

[11] Ayden, Y., Demirbag, M., \& Tatoglu, E. (2018). Post-Acquisition strategies of Turkish MNEs. Turkish Multinationals, 169-186. https://doi.org/10.1007/978-3-31 9-57294-9.

[12] Bahcheli, T. S. (2013). Turkey and the EC: The strains of association. Journal of European Integration, 3(2), 221-237. https://doi.org/10.1080/07036338008428759.

[13] Balasubramanyam, V. N. (2015). Foreign Direct Investment in Turkey. The Economy of Turkey since Liberalization, 112-130. https://doi.org/10.1007/978-1-349-24464-5_6.

[14] Barry, F. (2013). Economic Integration and Convergence Processes in the EU Cohesion Countries. Journal of 
Common Market Studies, 41(5), 897-921. https://doi.org/1 0.1111/j.1468-5965.2003.00468.x.

[15] Bilgel, F., \& Karahasan, B. C. (2016). Thirty Years of Conflict and Economic Growth in Turkey: A Synthetic Control Approach Frrat Bilgel and Burhan Can Karahasan. LSE ‘Europe in Question’ Discussion Paper Series, (112).

[16] Cambazoglu, B., \& Karaalp, H. S. (2014). Does foreign direct investment affect economic growth? The case of Turkey. International Journal of Social Economics, 41(6), 434-449. https://doi.org/10.1108/IJSE-02-2012-0173.

[17] Celebioglu, F., \& Dall'erba, S. (2010). Spatial disparities across the regions of Turkey: An exploratory spatial data analysis. Annals of Regional Science, 45(2), 379-400. https://doi.org/10.1007/s00168-009-0313-8.

[18] Cidob. (2011). Economic and Social Indicators of Turkey. CIDOB International Yearbook 2011 Country Profile: Turkey, 2011, 249-257.

[19] Coskun, A., \& Gungormus, A. H. (2015). Exploring the Accounting History Research in Turkey: Publishing Patterns of Academicians. Mediterranean Journal of Social Sciences, 6(4), 323-332.https://doi.org/10.5901/mjss.2015 .v6n4p323.

[20] Cuervo-Cazurra, A. (2012). Extending theory by analyzing developing country multinational companies: Solving the Goldilocks debate. Global Strategy Journal, 2(3), 153-167. https://doi.org/10.1111/j.2042-5805.2012.01039.x.

[21] Daron Acemoglu, M. U. (2015). The Ups and Downs of Turkish Growth, 2002-2015: Political Dynamics, the European Union and the Institutional Slide. 2002-2015.

[22] Deichmann, J., Karidis, S., \& Sayek, S. (2013). Foreign direct investment in Turkey: Regional determinants. Applied Economics, 35(16), 1767-1778.https://doi.org/10. 1080/0003684032000126780.

[23] Dumludag, D. (2009). An Analysis of the Determinants of Foreign Direct Investment in Turkey: the Role of the Institutional Context. Journal of Business Economics and Management, 10(1), 15-30. https://doi.org/10.3846/1611-1 699.2009.10.15-30.

[24] Durnel, J. C. (2012). The effects of Foreign direct investment on Turkish economy.

[25] Erdil, E., \& Karagol, B. (2014). Information and Communication Technologies in Turkey and Other OECD Member Countries. Ekonomik Yaklasim, 23(85), 1. https://doi.org/10.5455/ey.34100.

[26] Erdilek, A. (2008). Internationalization of Turkish MNEs.

[27] Erkilek, A. (2008). A comparative analysis of inward and outward FDI in Turkey. İktisat İşletme ve Finans, 20(233). https://doi.org/10.3848/iif.2005.233.3044

[28] Esiyok, B. (2010). The Determinants of Foreign Direct Investment in Turkey: An Empirical Analysis Bulent Esiyok Thesis submitted for the award of Doctor of Philosophy the University of Greenwich Business School June 2010. Exchange Organizational Behavior Teaching Journal, (June).

[29] Goldthau, A., Keating, M., Kuzemko, C., \& Raszewski, S. (2018). Emerging economies and energy: the case of
Turkey. Handbook of the International Political Economy of Energy and Natural Resources, (October), 263-278. https://doi.org/10.4337/9781783475636.00028.

[30] Greenaway, D., \& Sapsford, D. (2015). Liberalization and the terms of trade in Turkey: A causal analysis. Applied Economics, 27(10), 953-959. https://doi.org/10.1080/0003 6849500000075 .

[31] Grubaugh, S. G. (2016). Determinants of Direct Foreign Investment. The Review of Economics and Statistics, 69(1), 149. https://doi.org/10.2307/1937913.

[32] Hakura, F. (2013). Briefing paper After the Boom : Risks to the Turkish Economy. Chatham House, (August).

[33] İdikut Özpençe, A. (2017). Economic Stability and Growth: The Case of Turkey. Research in Applied Economics, 9(4), 41. https://doi.org/10.5296/rae.v9i4.12041.

[34] Isiks, A. Z., Isiksal, H., \& Jalali, H. (2018). The Impact of Foreign Direct Investment on Turkish Economy 2010-2016. Economics, 5(2), 69-81. https://doi.org/10.1515/eoik-2017 -0019 .

[35] Kaartemo, V. (2012). Döner Ekonomi - Analysis of Turkish Economy. Electronic Publications of Pan-European Institute, (December 2008), 1-80.

[36] Keyhani, M., \& Madhok, A. (2012). Acquisitions as entrepreneurship: asymmetries, opportunities, and the internationalization of multinationals from emerging economies. Global Strategy Journal, 2(1), 26-40. https://doi.org/10.1111/j.2042-5805.2011.01023.x.

[37] Keyman, E. F., \& Aydın-düzgit, S. (2013). Transforming Turkey-EU Relations: Ground for Hope. Global Turkey in Europe, (March), 275.

[38] Khan, M. A. (2014). Challenges for MNEs Operating in Emerging Markets. Available via: Www: Aabri. Com/LV2014Manuscripts/LV14045. Pdf. [Retrieved on 05/05/2016], 18(2), 1-16. https://doi.org/10.1002/cm.2001 0.

[39] Kooros, S. K., \& Semetesy, M. (2010). The Impact of Oil Prices on Employment *. Finance and Economics, 5(5). https://doi.org/10.2139/ssrn.1869931

[40] Özaslan, M., Dincer, B., \& Özgür, H. (2011). Regional Disparities and Territorial Indicators in Turkey: Socio-Economic Development Index (SEDI). Development.

[41] Prime, T. (2012). the Likely Effects of Turkey' S Membership. (December).

[42] Reisman, A., Capar, I., \& Aktas, E. (2011). Turkey's Development: The Role of Technology Transfer. SSRN Electronic Journal, 1-49. https://doi.org/10.2139/ssrn.6078 41.

[43] Revoltella, D. (2011). Competitiveness Report 2011. 1-216.

[44] Sat, N. A. (2011). Innovation strategies of MNCs: A case study from Turkey. Gazi University Journal of Science, 24(4), 945-957.

[45] Schönfelder, N., \& Wagner, H. (2019). Institutional convergence in Europe. Economics, 13(2018). https://doi.o rg/10.5018/economics-ejournal.ja.2019-3. 
[46] Shaydullin, H. (2010). Turkey \& The Construction Services Cluster. Spring, 1-33.

[47] Sözen, A. (2010). A paradigm shift in Turkish foreign policy: Transition and challenges. Turkish Studies, 11(1), 103-123. https://doi.org/10.1080/14683841003747062.

[48] Tatoglu, E., \& Erdal, F. (2012). Locational Determinants of Foreign Direct Investment in an.

[49] Taylor, P., \& Kosekahyaoglu, L. (2010). Journal of Business Economics and Management a comparative analysis of FDI in Turkey and the CEECs : Is there any link between FDI and trade? A COMPARATIVE ANALYSIS OF FDI IN TURKEY AND THE CEECS: IS THERE ANY LINK BETWEEN FDI AND TRADE? 1699(May 2015), 37-41. https://doi.org/10.1080/16111699.2006.9636140.

[50] Temiz, D., \& Gökmen, A. (2009). Foreign Direct Investment and Export in Turkey: The Period of 1991-2008. EconAnadolu 2009: Anadolu International Conference in Economics, 0(14), 1-29.

[51] Tevfik F. Nas. (2013). an Overview of the Turkish Economy: 1920(1) 80. Tracing the Economic Transformation of Turkey from the 1920 s to EU Accession.

[52] Vale. (2011). Turkish MNEs steady on their course despite crisis, survey finds. 1-26.

[53] Wall, L. D., \& Pringle, J. J. (2007). Alternative Explanations of Interest Rate Swaps: A Theoretical and Empirical Analysis. Financial Management, 18(2), 59. https://doi.org $/ 10.2307 / 3665893$

[54] Yaprak, A., \& Karademir, B. (2010). The internationalization of emerging market business groups: An integrated literature review. International Marketing Review, 27(2), 245-262.https://doi.org/10.1108/02651331 011037548 .

[55] Yaprak, A., Yosun, T., \& Cetindamar, D. (2018). The influence of firm-specific and country-specific advantages in the internationalization of emerging market firms: Evidence from Turkey. International Business Review, 27(1), 198-207. https://doi.org/10.1016/j.ibusrev.2017.07. 001.

[56] Yavan, N. (2012). Türkiye'nin Yurt Dışındaki Doğrudan Yatırımları: Tarihsel ve Mekânsal Perspektif. Bilig, 237270.

[57] Yildirim, C. (2017). Turkey's outward foreign direct investment: Trends and patterns of mergers and acquisitions. Journal of Balkan and Near Eastern Studies, 19(3), 276-293. https://doi.org/10.1080/19448953.2017.1277084. 